\title{
Schoolteachers' knowledge of common health problems in Bahrain
}

F.A. Alnasir' and J.H. Skerman ${ }^{2}$

$$
\begin{aligned}
& \text { معارف معلّمي المدارس حول المشكاتلات الصحية الشائعة في البحرين }
\end{aligned}
$$

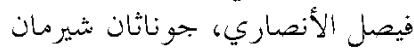

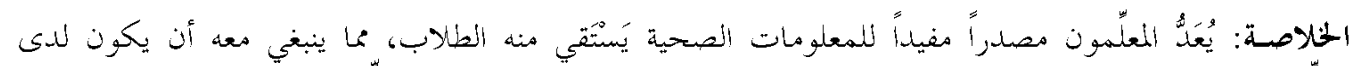

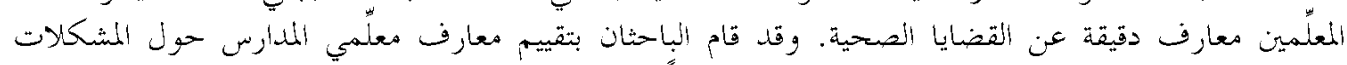

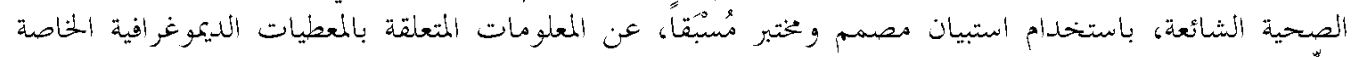

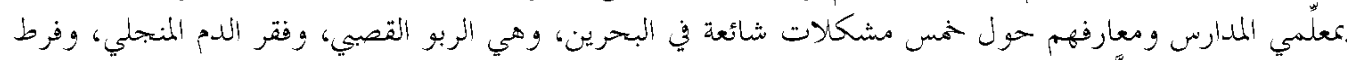

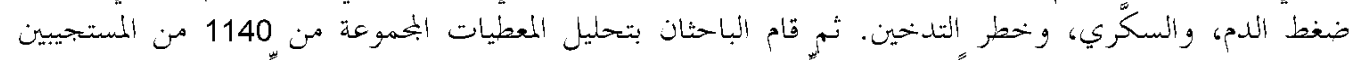

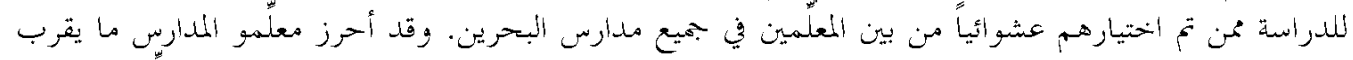

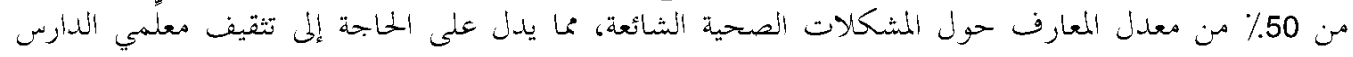

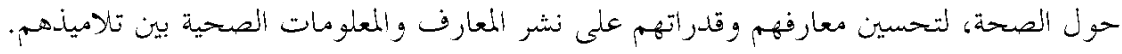

ABSTRACT Schoolteacher could be a useful source of health information for students but that they themselves would have to possess adequate and accurate knowledge of health issues. We assessed Bahraini schoolteachers' knowledge of some common health problems using a pre-tested, structured questionnaire which requested information on schools, teachers' demographic data, and knowledge about 5 common health problems in Bahrain: bronchial asthma, sickle-cell anaemia, hypertension, diabetes mellitus and the dangers of smoking. We analysed the data on 1140 respondents from a random selection of teachers in all schools in Bahrain. The schoolteachers scored only around $50 \%$ on average for knowledge about common health problems which indicates a need to educate schoolteachers about health in order to improve their knowledge and their capability to disseminate health knowledge and information to students.

\section{Connaissance des problèmes de santé courants par les enseignants scolaires à Bahreïn}

RÉSUMÉ Les enseignants scolaires pourraient représenter une source utile d'information sur la santé pour les élèves mais il devraient eux-mêmes posséder des connaissances suffisantes et exactes sur les questions de santé. Nous avons évalué les connaissances des enseignants scolaires Bahreïnites concernant des problèmes de santé courants à l'aide d'un questionnaire structuré, testé au préalable, qui cherchait à recueillir des informations sur les écoles, des données démographiques concernant les enseignants et la connaissance de cinq problèmes de santé courants à Bahreïn : l'asthme bronchique, la drépanocytose, l'hypertension, le diabète sucré et les dangers du tabagisme. Nous avons analysé les données de 1140 répondants dans une sélection aléatoire d'enseignants de toutes les écoles de Bahreïn. Les enseignants n'ont obtenu qu'un score d'environ $50 \%$ en moyenne pour les connaissances concernant ces problèmes de santé courants, ce qui indique une nécessité d'éduquer les enseignants en matière de santé afin d'améliorer leurs connaissances et leur capacité à diffuser des connaissances et des informations sur la santé aux élèves.

${ }^{1}$ Department of Family and Community Medicine, College of Medicine and Medical Sciences, Arabian Gulf University, Bahrain.

${ }^{2}$ Department of Anaesthesia and Intensive Care, College of Medicine and Medical Sciences, Arabian Gulf University and Salmaniya Medical Complex, Bahrain.

Received: 01/07/03; accepted: 29/10/03

البحلة الصحية لشرق المثو سط، منظمة الصحة العالمية، البحلد العاشر، العددان ع-0، ع + • 


\section{Introduction}

Schoolteachers form a group with great potential for influencing the health knowledge and attitudes of students and other population groups. Schoolteachers' perceptions of health, their attitudes and practices, and their knowledge of common health problems could be essential factors in optimizing their roles as health educators in society.

Many adult behaviour patterns and attitudes develop in early childhood. In addition there is a growing acceptance of the need for health education at primary school age. For example, it has been found that various interventions such as improving teachers' awareness of cancer education issues and providing appropriate cancer education resources might increase the level of primary school-based cancer education [1].

Schoolteachers are expected to be role models so that students can emulate and adopt their behaviour and attitudes. In Sweden, the majority of school pupils thought that schoolteachers were the best sources of information for sexually transmitted infections and sexuality [2]. Schoolteachers are also considered the major source of information for their students and would appear to be suitable as health educators [3]. In Australia, teachers and the clergy have been identified as "gatekeepers" who might serve as a first line of assistance for distressed young people [4].

Since current emphasis in health education is on prevention of serious illness through lifestyles that promote wholeness, teachers are well placed professionally to carry out health education at school $[5,6]$. Teachers' education is considered a major factor in the effective implementation of comprehensive school health [7]. Attitudes, behaviour and general knowledge are disseminated to the students from the teachers, either deliberately or unconsciously. In order to raise students' health knowledge and improve their attitudes toward health, they should be placed in an appropriate environment that is based on 3 main determining factors: teachers, school and society (including home).

School and health professionals should continue to advocate school-wide policies and programmes that support both students and teachers if the goal of an integrated healthy school environment is to be realized [8]. Ministries of education and health should organize seminars on health education [9]. Educational health packages could be developed with collaboration between teachers who have an understanding of the principles of curriculum design and health professionals who are fully aware of health problems [10]. Development efforts by teachers, including training and ongoing reinforcement to increase their sense of preparedness, have significant effects in the classroom [11]. In Nigeria, most teachers felt that health education was important and should be an integral part of the curriculum [12]. Multicultural attitudes and knowledge on the part of teachers changed in a positive direction when candidates attended a teacher preparation programme [13].

It is reported that the formation of a population's healthy lifestyle, which is one of the main tasks of Soviet medicine, can be accomplished with the help of school health education teams [14]. It has been documented, however, that in Bahrain school health education is not included in the curriculum [15]. Few states in the United States of America include health education in their state tests, and elementary school teachers often do not feel it is an important subject and therefore spend insufficient time on health instruction in the classroom [16].

بلملة الصحية لشرق المتو سط، منظمة الصحة العالمية، المحلد العاشر، العددان ع-0، ع • • 
It was our goal to study teachers' awareness about common health problems in Bahrain. We hypothesized that the teachers were well informed about these problems and hence would be able to disseminate information to others, specifically students.

\section{Methods}

Information was collected about the schools in Bahrain and permission for conducting the study was obtained from the Ministry of Education, who sent out an information circular to all schools in the country. The study was carried out during 1997-1998. The target population was all Bahraini teachers of all disciplines in 49 randomly selected schools.

Schools in the 5 geographic regions of Bahrain (Muharraq, Manama, Northern area, Central area and Western area) were selected for this study. The total number of schools in these areas is 152, with a total of 3360 teachers. A random sample of 49 schools was selected. Stratified random sampling was done, giving appropriate representation to the 5 regions, and taking into account the number of Bahraini teachers in each school, the type of school, and the locality. All 1248 Bahraini teachers in those schools were included in the study.

The study tool for this investigation was a questionnaire. Based on a comprehensive review of the literature, a 4-item survey was designed. Items addressed each of the following areas: information about the school, teachers' demographic characteristics, teachers' health perceptions, and health knowledge. The questionnaire was adapted to the local language and designed in a simple way to make it easy for the selected teachers to read and complete. The face value and content validity of the questionnaire were tested by distributing it to doctors in various specialties and obtaining their feedback. It was also tested for repeatability by sending it again to the same doctors after a 1-week lapse. A pilot study was done to test the various areas of the questionnaire.

The health information portion of the questionnaire was aimed at collecting information about the teachers' health status and their experiences of illness. Five common health problems in Bahrain (asthma, sicklecell anaemia, hypertension, diabetes mellitus and the dangers of smoking) were chosen because of their high prevalence among Bahrainis. The teachers were asked questions (a total of 48: 8 questions for the smoking problem and 10 for each of the others) related to signs, symptoms and complications of those problems. Some untrue information for each problem was included to test the teachers' knowledge. The teachers were asked to give their response to the pre-set questions by writing "Yes” (agree), "No" (do not agree) or "Do not know" to the answer. Each blank space was considered a missing value (i.e. teachers did not respond to it).

After analysing the responses, a score of 1 was given for the correct answer and 0 for other answers (wrong, missing or "Do not know" answers).

No questions inquiring about whether the teachers had received any formal training or special education about common health problems were included.

The head teacher of each school was given complete information on the study, either by telephone or through direct contact. The questionnaires were delivered to the teachers in the selected schools in the morning and collected at the end of the same day or after a maximum of 2 days. An accompanying letter was written to the teachers giving them information on the study, its aims, how to complete the questionnaire and requesting their cooperation.

بلملة الصحية لشرق المتو سط، منظمة الصحة العالمية، البحلد العاشر، العدذان ع-0، ع • • 
Data were analysed using SPSS. Results were cross-tabulated and chi-squared calculated. The knowledge portions of the data were scored and assessed as percentage scores.

\section{Results}

Of the 1254 teachers included in the sample, 1140 (91\%) responded and 114 (9\%) did not. Efforts were made to obtain the questionnaire from the non-respondents, but without success. The general characteristics of these non-respondents, such as age, sex and type of school, were investigated and were not found to differ from those of the respondents. There were 679 (60\%) female respondents and 461 (40\%) male. Age range was 20-58 years (mean 32.7 years, median 32 years, standard deviation [SD] 6.17). Only $15 \%$ of the teachers stated they were above 40 years of age. Of the 220 teachers who did not wish to disclose their ages (19\%), the majority (94\%) were female. Of the responding teachers, $78 \%$ were married, $20 \%$ were single and $2 \%$ were either divorced or widowed. There were 774 teachers who were married and had children (range 1-16 children, mean 3). More male teachers than female teachers had children (65\% compared to $35 \%)$.

Of the 1091 who responded to the question related to the teachers' level of education, $19 \%$ had only high school education and $81 \%$ had higher education, which includes a Diploma or Bachelor's degree. Teachers in primary and intermediate schools were younger ( $\leq 32$ years) $(P<$ 0.01 ) and more of them had degres than secondary school teachers. More females than males had higher education. Of the total, 29\% taught science subjects, including mathematics, and $71 \%$ taught arts subjects. There were 1068 responses (94\%) to the question about the duration of occupation. Duration ranged from 1 year to 35 years (mean 12.3 years, SD 7.3). Only 6\% of the teachers were smokers, of whom the majority (94\%) were male, while $4 \%$ were ex-smokers. Regarding alcohol consumption, since it is not usual in an Islamic country, not all who drink admit to it, and the others may find the question offensive. Of the $98 \%$ who responded to this question, only 14 (1\%), all of whom were male, admitted to drinking alcohol. Some $40 \%$ of the teachers were the heads of the household, and 35\% said they shared that responsibility.

Table 1 shows the teachers' responses to questions on their own health and healthrelated attitudes. The health status of the teachers was satisfactory as only $16 \%$ had any acute illness during the past 6 months.

The total scores for each teacher, which represented correct answers, ranged between 0 and 41 (mean 21.9, median 24, SD 9.3). Only 1 teacher obtained the highest score, but there were 39 teachers (3\%) who scored 0, i.e. no knowledge at all. Table 2 shows the scores for each health problem. The total scores for knowledge, after categorizing into 2 groups (group $1=\leq 24$, group $2=>24$ ) according to the median, were studied in relation to all other variables in the study (Table 3 ). There were a large number of missing values on the topics of sickle-cell anaemia and asthma, while there were no missing values on knowledge related to hypertension, diabetes mellitus or the dangers of smoking.

A higher percentage of females than males were teaching science, $23 \%$ compared with $16 \%$ (chi-squared $7.225, P$ $<0.5)$. More of the younger teachers $(\leq 32$ years) were teaching science subjects (46\%), while more of the older teachers (> 32 years) were teaching arts subjects (77\%) (chi-squared 20.81, $P<0.001$ ). 


\begin{tabular}{|c|c|c|c|c|c|c|}
\hline \multirow[t]{2}{*}{ Variable } & \multicolumn{2}{|c|}{ Yes } & \multicolumn{2}{|c|}{ No } & \multicolumn{2}{|c|}{$\begin{array}{l}\text { Did not } \\
\text { respond }\end{array}$} \\
\hline & No. & $\%$ & No. & $\%$ & No. & $\%$ \\
\hline \multicolumn{7}{|l|}{$\begin{array}{l}\text { Suffered from any acute } \\
\text { illness during the past }\end{array}$} \\
\hline 6 months & 179 & 16 & 936 & 82 & 25 & 2 \\
\hline Any chronic illness & 344 & 30 & 759 & 67 & 37 & 3 \\
\hline Family illness & 322 & 28 & 785 & 69 & 33 & 3 \\
\hline Doing exercise & 191 & 17 & 862 & 76 & 87 & 8 \\
\hline \multirow[t]{2}{*}{ Hospital admissions $^{a}$} & 137 & 12 & 963 & 85 & 40 & 4 \\
\hline & \multicolumn{2}{|c|}{ Good } & \multicolumn{2}{|c|}{ Unsatisfactory } & \multicolumn{2}{|c|}{$\begin{array}{c}\text { No } \\
\text { knowledge }\end{array}$} \\
\hline $\begin{array}{l}\text { Teachers' perception of } \\
\text { their general health }\end{array}$ & 930 & 82 & 100 & 9 & 68 & 6 \\
\hline $\begin{array}{l}\text { Perception of health } \\
\text { services in Bahrain }\end{array}$ & 762 & 67 & 265 & 23 & 113 & 10 \\
\hline
\end{tabular}

In general, teachers who had no chronic illness had better health knowledge for each category of health knowledge (chisquared $15.8, P<0.001$ ). Of the $93 \%$ of teachers who had not had any recent illness, $88 \%$ perceived their general health as satisfactory (chi-squared 67.1, $P<0.001$ ).
With regard to the dangers of smoking, surprisingly, it was found that there was no relationship between the smoking habit and knowledge about smoking $(P<0.9)$. However knowledge about smoking increased as the number of years of occupation increased (chi-squared 11.673, $P<0.001$ ).

\begin{tabular}{|c|c|c|c|c|c|c|c|}
\hline \multirow[t]{2}{*}{ Health problem } & \multicolumn{2}{|c|}{$\begin{array}{c}\text { Respondents } \\
\quad(n=1140)\end{array}$} & \multirow{2}{*}{$\begin{array}{c}\text { No. of } \\
\text { questions }\end{array}$} & \multicolumn{3}{|c|}{ Score } & \multirow[t]{2}{*}{$S D$} \\
\hline & No. & $\%$ & & Range & Mean & Median & \\
\hline Sickle-cell anaemia & 1053 & 92 & 10 & $0-10$ & 4.88 & 5 & 1.980 \\
\hline Smoking & 1067 & 94 & 8 & $0-8$ & 5.28 & 6 & 1.852 \\
\hline Asthma & 1029 & 90 & 10 & $0-10$ & 5.16 & 5 & 2.185 \\
\hline Hypertension & 969 & 85 & 10 & $0-10$ & 3.00 & 3 & 1.899 \\
\hline Diabetes mellitus & 1064 & 93 & 10 & $0-10$ & 5.34 & 6 & 2.133 \\
\hline
\end{tabular}

$S D=$ standard deviation

لبحلة الصحية لشرق المثتوسط، منظمة الصحة العلمية، البحلد العاشر، العدذان ع-0، ع • • 
Table 3 Correlation of some characteristics of teachers to better knowledge of five common health problems in Bahrain

\begin{tabular}{lcc}
\hline Characteristic & Better knowledge & P-value \\
\hline $\begin{array}{l}\text { Duration of occupation } \\
\text { as a teacher }\end{array}$ & Fewer years $>$ more years & $<0.05$ \\
Type of school & Primary + intermediate $>$ secondary & $<0.02$ \\
Sex & Female $>$ male & $<0.001$ \\
Marital status & Married $>$ single & $<0.02$ \\
Teaching discipline & Science $>$ arts & $<0.02$ \\
Recent illness & No recent illness $>$ having recent illness & $<0.05$ \\
Chronic illness & No chronic illness $>$ having chronic illness & $<0.001$ \\
Family size & Smaller family size $>$ larger family size & $<0.01$ \\
\hline
\end{tabular}

Table 4 shows some characteristics that were found to have a significant relationship with teachers having adequate knowledge ( $\geq$ mean) about diabetes mellitus. Knowledge of other health problems was found not to be related to the teachers' characteristics.

There was no relationship between suffering from chronic illness and knowledge about asthma, sickle-cell anaemia or the

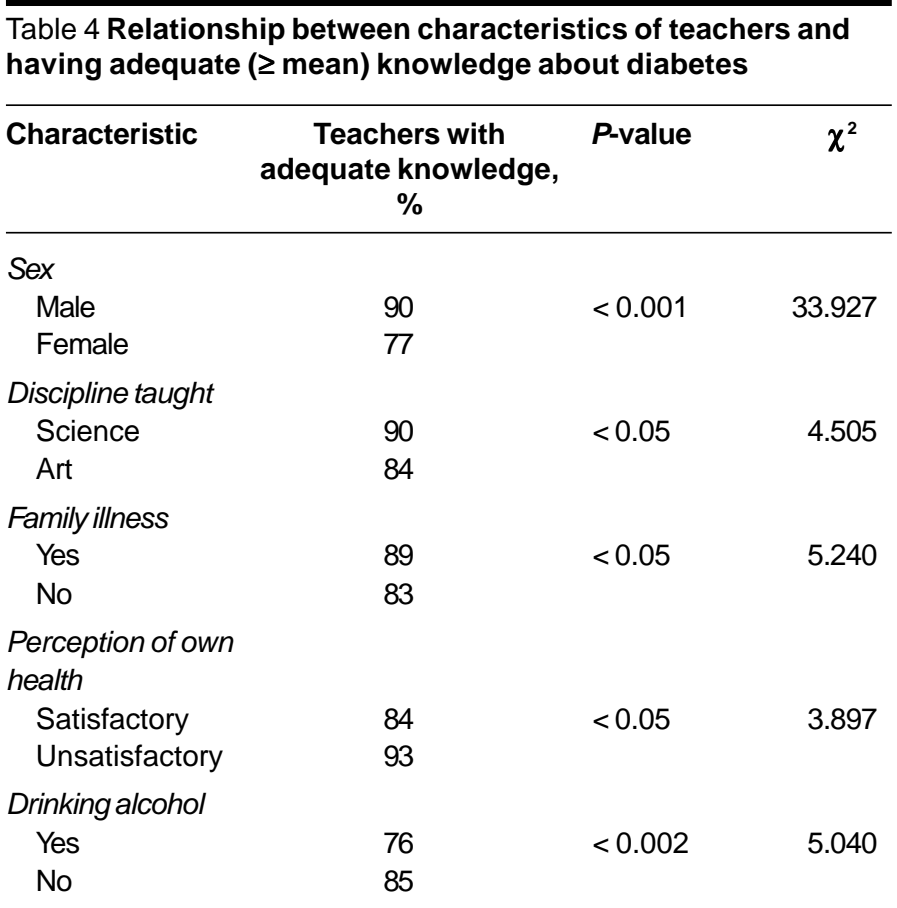

بلملة الصحية لشرة المتو سط، منظمة الصحة العالمية، البحلد العاشر، العلدان ع-0، ع • • 
dangers of smoking. There was a significant relationship between suffering from chronic illness and knowledge about diabetes mellitus (chi-squared 9.2, $P<0.02$ ) and knowledge about hypertension (chisquared $6.4, P<0.001$ )

\section{Discussion}

The majority of the teachers who participated in this study were young adults, and most had a university degree, either a Diploma or Bachelor degree. Most of the teachers were female, and we found they had better health knowledge than the males. A study done in the United States of America indicated that students' attitudes improved if their teachers were more educated and older. It was reported that the students' perception and attitude regarding adolescent homosexuality varied with the teacher's sex, age, educational level and teaching status [17].

The overall knowledge of the schoolteachers was found to be average in the areas related to sickle-cell anaemia, asthma and diabetes mellitus. While it was poor ( $<$ mean) in the area of hypertension, they had a good ( $\geq$ mean) knowledge of the dangers of smoking. Considering that the prevalence of these problems is high in Bahrain and the surrounding areas (3\%-5\% for sickle-cell anaemia, 25\% for diabetes mellitus, 5\% for bronchial asthma and approximately $15 \%$ for hypertension) [18], it is alarming that schoolteachers are not more aware of the problems. It is not surprising therefore if students lack information about such problems.

Teachers who had personal experience of illness, i.e. chronic or acute illness, either at the time of the study or earlier in life, or who had a family member with a significant illness, knew more in the areas of diabetes mellitus and hypertension. Both of these are chronic conditions and are very common in our community. This could explain why teachers were more informed in these 2 areas than the other areas

There was no relationship between teachers' perceptions regarding their own health or the health services in Bahrain and their knowledge of common health problems. This finding was supported by results of another study which found that teachers' health beliefs are not linked to whether teachers teach health generally [19].

Surprisingly, primary and intermediate school teachers had better knowledge than secondary school teachers. This could be explained by the fact that they may be younger and more of them have university degrees. Such findings regarding knowledge about common diseases are supported by studies in other parts of the world. A study in Brazil found that in areas where helminthic diseases are known to have been present for a long time, teachers and pupils still had little information on them, nor were they aware of the mechanism of transmission [20].

Another barrier to quality health instruction is when little or no in-service training is available for teachers. Several conditions are necessary for the development of learning opportunities allowing teachers freedom to develop new understandings of teaching and learning. Poor knowledge of health can be attributed to the fact that health education is not a priority at many schools, and can also be related to the fact that health education questions are usually absent from end of year examinations [16]. Most teachers in our study were selftaught with regard to health education as there is no formal training, and relied primarily on traditional teacher-centred instruction methods. In order to deliver effective health education in schools,

لبحلة الصحية لشرق المثتوسط، منظمة الصحة العلمية، البحلد العاشر، العدذان ع-0، ع • • 
teachers require a substantial body of knowledge and a variety of skills [21,22]. The type of training programme offered usually has a marked influence on the length and type of programme they offer to their students [23].

Our findings are in agreement with those of several other reports which indicated that teachers' health knowledge is deficient and this may ultimately affect their ability either to deliver health education or to manage acute health problems in school. In one study it was found that the majority of teachers encounter child abuse among their students although they did not receive sufficient education on how to address it [24]. In another study it was reported that teachers needed more knowledge regarding head lice and were significantly more knowledgeable as teaching experience increased [25]. In an Indian study about sex education, pupils in one school were reassessed after a health talk and distribution of a handout. Despite having had no formal sex education, most respondents were reasonably well informed about the transmission of HIV. Media teachers and health workers were quoted as the main sources of knowledge [26]. In a Canadian study on the effectiveness of school-based sexual health education, it was found that it depended in part on the preparation of the teachers [24]. The delivery of consistently high quality sexual health education in schools requires that all teachers of sexual health education are adequately prepared and acquire a substantial body of knowledge.

\section{Conclusion}

We found that there was a deficiency in teachers' health knowledge and therefore there is a need to educate schoolteachers about health, particularly about health problems prevailing in the society. There should be regular pre-service and in-service training regarding such problems. Health and education ministries in Bahrain should organize joint seminars for schoolteachers on health education to improve their level of health awareness. This would help teachers to develop health education packages in collaboration with the curriculum designers and health professionals to tackle current knowledge about health-related problems.

\section{References}

1. Carey $\mathbf{P}$ et al. Cancer education and the primary school teacher in England and Wales. Journal of cancer education, 1995, 10(1):48-52.

2. Persson E, Sandstrom B, Jarlbro G. Sources of information, experiences and opinions on sexuality, contraception and STD protection among young Swedish students. Advances in contraception, 1992, 8(1):41-9.

3. McGovern M, Barry MM. Death education: knowledge, attitudes and perspectives of Irish parents and teachers. Death studies, 2000, 24(4):325-33.
4. Leane W, Shute R. Youth suicide: the knowledge and attitudes of Australian teachers and clergy. Suicide and lifethreatening behaviour, 1998, 28(2):16573.

5. Mull, SS. The role of the health educator in development of self-esteem. Journal of health education, 1991, 22:349-51.

6. Masvidal RM et al. La educación sanitaria en la escuela [Health education in school]. Atención primaria 1995, 15(6): 369-70, 372.

بليحلة الصحية لشرة المتو سط، منظمة الصحة العالمية، البحلد العاشر، العلددان ع-0، ع • • 
7. Wood DN. Teacher credential candidates' perceptions of the need for pre-service training in comprehensive health education. Paper presented at the annual meeting of the American School Health Association, Milwaukee, Wisconsin, 1995.

8. Kubik MY et al. Food-related beliefs, eating behavior, and classroom food practices of middle school teachers. Journal of school health, 2002, 72(8):339-45.

9. Brook U. Teachers' attitudes towards AIDS: an explorative study in Israel. Patient education and counseling, 1994, 24(3):337-40.

10. Henry RL et al. Integrated health and education input in the development of educational resources about asthma for schools. Journal of paediatric and child health, 1994, 30(6):492-6.

11. Hausman AJ, Ruzek SB. Implementation of comprehensive school health education in elementary schools: focus on teacher concerns. Journal of school health, 1995, 65(3):81-6.

12. Fabiyi AK, Blumenthal DS. Health education in Nigerian secondary schools. Journal of community health, 1991, 16(3):151-8.

13. Capella-Santana N. Voices of teacher candidates: positive changes in multicultural attitudes and knowledge. Journal of educational research, 2003, 96(3):182-92.

14. Tsurikov VT, Gavriushenko VV. Iz opyta organizatsii smotra-konkursa shkol'nykh sanprosvetagitbrigad. [Experience in organizing competition of school health education teams]. Sovetskoe zdravookhranenie, 1991, (5): 54-6.

15. Roemer R. Legislative action to combat the world tobacco epidemic, 2nd ed. Geneva, World Health Organization, 1993:210.
16. Telljohann SK et al. Effects of an inservice workshop on the health teaching self-efficacy of elementary school teachers. Journal of school health, 1996, 66(7):261-5.

17. Telljohann SK et al. Teaching about sexual orientation by secondary health teachers. Journal of school health, 1995, 65(1):18-22.

18. Health Information Directorate. Health statistics report - 2003. Bahrain, Ministry of Health, 2003.

19. Carey $P$ et al. Is health locus of control related to health education activity? Psychological reports, 1995, 76(3 pt 2): 1389-90.

20. Dos Santos MG et al. Educacao em saúde em escolas públicas de 1 grau da periferia de Belo Horizonte, MG, Brasil. II - Conhecimentos, opinioes e prevalencia de helmintiases entre alunos e professors. [Health education in 1st grade public schools at the periphery of Belo Horizonte, Brazil. II. Knowledge, opinion and prevalence of helminthiasis among students and teachers]. Revista do Instituto de Medicina Tropical de São Paulo, 1993, 35(6):573-9.

21. Gingiss PL, Basen-Engquist K. HIV education practices and training needs of middle school and high school teachers. Journal of school health, 1994, 64(7): 285-90.

22. McKay A, Barrett M. Pre-service sexual health education training of elementary, secondary, and physical health education teachers in Canadian faculties of education. Canadian journal of human sexuality, 1999, 8(2):91-101.

23. Sequier A, Demarteau M, Pereira M. L'analyse des représentations: un moyen d'évaluer la formation des enseignants en éducation pour la santé. [Representational analysis: a means to

لبحلة الصحية لشرق المثتوسط، منظمة الصحة العلمية، البحلد العاشر، العدذان ع-0، ع • • 
evaluate teacher training in health education]. Promotion \& education, 1994, $1(3): 14-8$.

24. Abrahams N, Casey K, Daro D. Teachers' knowledge, attitudes and beliefs about child abuse and its prevention. Child abuse and neglect, 1992, 16(2):229-38.

25. Kirchofer GM, Price JH, Telljohann SK. Primary grade teachers' knowledge and perceptions of head lice. Journal of school health, 2001, 71(9):448-52.

26. Agrawal $\mathrm{KH}$ et al. Knowledge of and attitudes to HIV/AIDS of senior secondary school pupils and trainee teachers in Udupi District, Karanataka, India. Annals of tropical paediatrics, 1999, 19(2):1439.

\section{Mote from the Editor}

We would like to inform our readers that the next issue of EMHJ (Volume 10 Mo. 6) will be a Special Issue on Mutrition.

بلملة الصحية لشرة المتو سط، منظمة الصحة العالمية، البحلد العاشر، العلدان ع-0، ع • • 